Southern Illinois University Carbondale

OpenSIUC

Publications

Department of History

Fall 2007

\title{
"Complete Liberty"? Gender, Sexuality, Race, and Social Change on the Lower Columbia River, $1805-1838$
}

Gray H. Whaley

Southern Illinois University Carbondale

Follow this and additional works at: http://opensiuc.lib.siu.edu/hist_pubs

Copyright 2007 by American Society for Ethnohistory

Published in Ethnohistory, Vol. 54, No. 4 (Fall 2007) at 10.1215/00141801-2007-026

\section{Recommended Citation}

Whaley, Gray H. "'Complete Liberty"? Gender, Sexuality, Race, and Social Change on the Lower Columbia River, 1805-1838." (Fall 2007).

This Article is brought to you for free and open access by the Department of History at OpenSIUC. It has been accepted for inclusion in Publications by an authorized administrator of OpenSIUC. For more information, please contact opensiuc@lib.siu.edu. 


\title{
"Complete Liberty"? Gender, Sexuality, Race, and Social Change on the Lower Columbia River, I $805-1838$
}

Gray Whaley, Southern Illinois University

\begin{abstract}
This article analyzes social change in the emerging colonial world of the lower Columbia River from I805 to I838, particularly regarding gender and sexuality. It teases out distinctions among formal marriages, informal "custom of the country" arrangements, the exercise of sexual "liberties" by young Chinookan women, and prostitution, revealing much of the complex sexual interactions between natives and newcomers. Such a focus illuminates critical, interpersonal aspects of fur trade society in this region as it developed into a complex colonial milieu, reflecting both indigenous and Western interests. Lower Chinookans adapted slavery and trade practices to accommodate the demands of their own social stratification and the challenges brought by newcomers. Colonial accommodations were first limited by Western racial and economic ideologies, and subsequently by the gross power inequity caused by the collapse of the native population in the early I830s from malaria and other introduced diseases.
\end{abstract}

In the past two decades, scholars such as Sylvia Van Kirk and Jennifer S. H. Brown have established the importance of understanding the history of native women during the fur trade, and others have since broadened the field with sophisticated investigations of gender and sexuality during colonial encounters. In the greater lower Columbia River region, Chinookan women and their neighbors have been alternatively pitied as prostitutes and renowned for their influence in the history of the lower Oregon Country. ${ }^{1}$ For Van Kirk, the experiences of lower Chinookan women are excellent examples of sexual exploitation by colonials during the fur trade, while James Ronda casts these women as able traders who benefited from sexual labor. Contemporary accounts also diverge. Both ugly tales of ill treatment and statements that the young women of the lower Columbia

Ethnohistory 54:4 (Fall 2007) DOI IO.I2I5/O0I4I8OI-2007-026

Copyright 2007 by American Society for Ethnohistory 
enjoyed "complete liberty" in their premarital sexuality abound in colonial texts. These contradictions in the sources and the resulting scholarly differences continue to hinder the development of an inclusive regional history. Changing gender and sexual constructions reveal much about human relations both internally within societies and externally with outsiders and are thus crucial to indigenous-colonial studies. This article analyzes the often conflicting and problematic sources by looking at the roles of social status, race, gender, and sexual constructions from the Corps of Discovery (fall I805-spring I806) to the I830s, when disease epidemics decimated the lower Chinookan population and survivors began to lose control of their homelands. ${ }^{2}$

This is a study of colonialism that examines the creative and destructive interactions between indigenous and colonial peoples. Regardless of whether Americans or British controlled the trade ships that initiated contact in 1792 or the fort that followed in I8II, the success of the fur trade depended on how the native peoples of the lower Columbia participated. The region's fur trade was a series of negotiations among people with different interests, and it did not often follow a neat Indian-white pattern. Lower Chinookans of high and common status maneuvered themselves to benefit from the trade vis-à-vis people in and outside their villages. Company laborers and trappers included ethnic Europeans, Native Hawaiians (Kanakas), and eastern native peoples, all with their own interests in mind. Colonial officers had to negotiate the demands of distant imperial officials, local native people, and their strong-willed employees. With an overwhelmingly male colonial presence encountering native communities with normal sex ratios, gender and sexuality became important sites of negotiation. The result was a highly fluid colonial world. ${ }^{3}$

This study concerns mostly personal relations, particularly intermarriage, interracial sexuality outside of marriage, and prostitution. ${ }^{4}$ Contemporary writers often conflated these three "institutions," creating a problematic historical record and partly explaining the contradictions present in modern scholarship. Formal intermarriages, while relatively infrequent before the I820s, were nonetheless important, as they initially occurred among leaders and helped form political and economic ties. Later, they both created and reflected important changes in colonial and native societies. Informal "custom-of-the-country" marriages occurred more frequently, incorporating the knowledge, skills, and labor of local native women into the fur trade. Colonial texts, however, did not always distinguish these relationships from a range of other sexual encounters. Different Western observers described similar instances and relationships as both informal marriage and prostitution. Such distinctions are important 


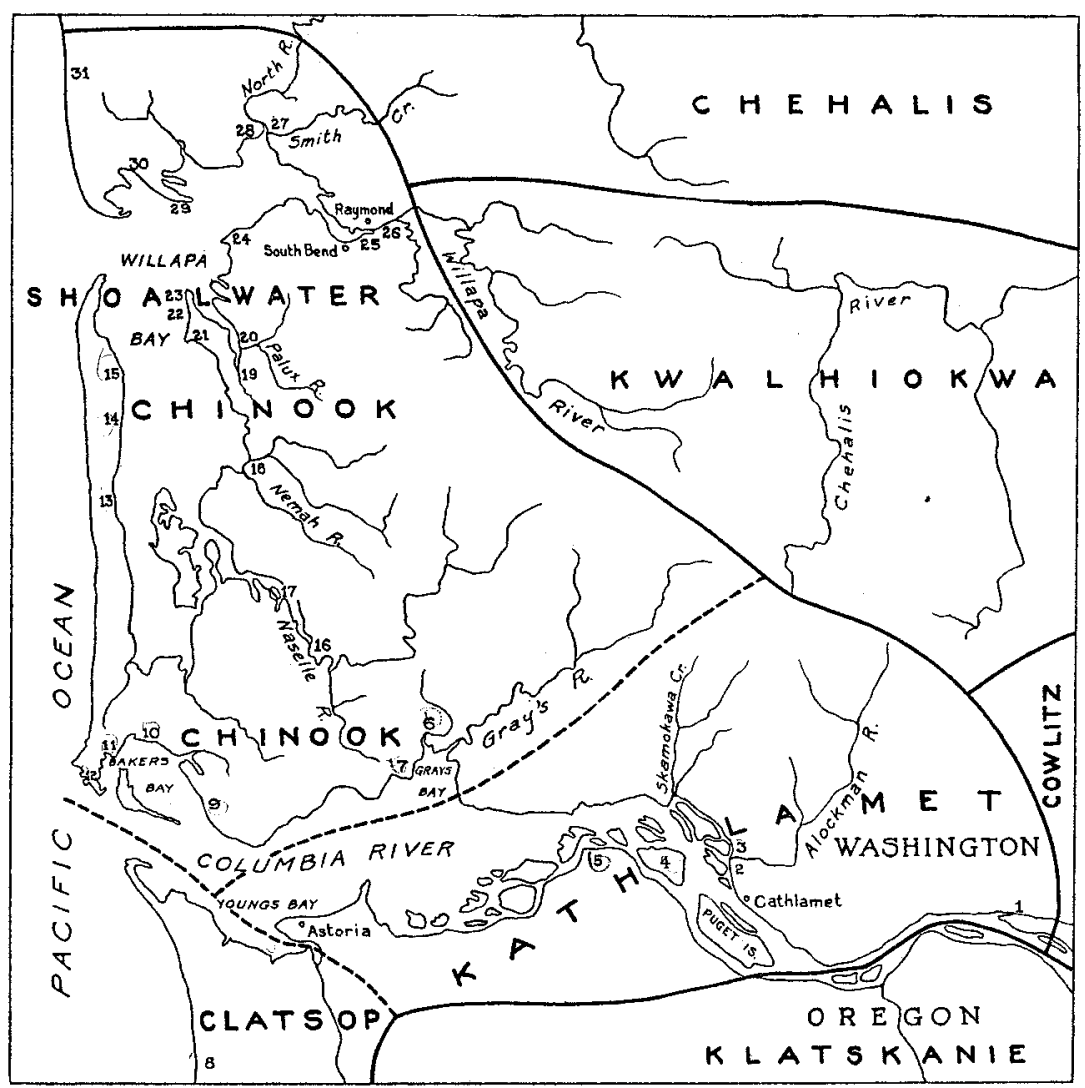

Figure I. Map of the territory of the Lower Chinook about I80o, from Verne Frederick Ray, "Lower Chinook Ethnographic Notes," University of Washington Publications in Anthropology 7 (1938): 37. Figures represent villages (see Ray, "Lower Chinook Ethnographic Notes" for key). Solid lines indicate linguistic stock boundaries; broken lines indicate dialect boundaries.

because nineteenth-century observers continue to inform our historical understanding, including the perpetuation of negative stereotypes about lower Chinookans. ${ }^{5}$ Moreover, such confusion leaves essential historical changes in the region unexplored and unexplained. Of the three "institutions," prostitution is the most perplexing. There was no clear precolonial native antecedent, narratives by "prostitutes" do not exist, and, as I have noted, contemporaries varied in their use of the term, all of which made a historical treatment difficult but not impossible. 
While marriage in some form is nearly universal, prostitution is a construction limited to cultures in which an individual recognized by society as a "prostitute" directly exchanges sex for money or material wealth. ${ }^{6}$ In early colonial lower Oregon, individuals with differing sexual norms in a shifting social and cultural landscape contested the characterization of both individual women as prostitutes and their actions as prostitution. For example, critics attempting to control and/or reform the trade colony most often leveled the charge of prostitution. In some cases, laboring men defended the reputation of the native women whom they had come to know, depend on, and even love. Still, the term prostitution best describes some sexual relations, albeit in a colonial setting in which ideals and practice often clashed and produced hybrid accommodations. Having carefully studied the interracial sexual relations on the lower Columbia from I805 to $\mathrm{I} 838$, I distinguish prostitutes in this case as women who were compelled to engage in brief sexual encounters often for the benefit of someone directing them. They were slaves or poor women forced by circumstance. By the I830s, these were the few women who colonial and native peoples agreed fit the role. Prostitution had by that time decreased and become marginalized; it rose and declined in relation to demographic and social changes in the region.

From I792 through the I830s, competing social, economic, and political actors created different gender relations and sexual exchanges; these creations were not "traditionally" native or European. As any instance of colonialism is shaped by individual interactions, personal relations embodied in the three "institutions" were among the most important sites of negotiations of power in the native-colonial world along the lower Columbia River through the I8zos.

\section{The Corps in Clatsop Country}

Arriving in the fall of 1805 , the Corps of Discovery led by Meriwether Lewis and William Clark met Chinookan peoples on the lower Columbia River who had been in direct contact with Western maritime traders since I792. Moreover, Spanish colonization of the Southwest and the maritime trade had profoundly changed the native Northwest through the smallpox epidemic of the early $\mathrm{I} 780 \mathrm{O}$ and the incorporation of horses by Plateau peoples. ${ }^{7}$ Although the Corps's writings were not the first documentation of encounters in the region, they were the first comprehensive ones; while culturally biased and sometimes contradictory, they are still useful for viewing a native world in the midst of great change. Despite the inhibitions one might expect, the Corps's journals freely addressed sexuality, 
and the group's observations readily found their way into print (in altered form). Lewis's published history of I8I4 was actually written by Nicholas Biddle, who was not an expedition member. Biddle sensationalized the original journals, changing details presumably to increase sales. Such was true generally of the journals-cum-travel-literature written during and about the early trans-Pacific trade, which was already taking shape before the Corps laid an Oregon claim for the United States. The works became so prevalent that Ross Cox worried that "I might subject myself to the charge of plagiarism ... if I touched on" a discussion of Hawaiian culture and "vices." Cox's complaint that charges "of lasciviousness ... . [are] too general" and his proto-relativist stance that "English chastity" is not judged by "the disgusting conduct of the unfortunate females who crowd our sea-ports and ships" was not typical of his time. ${ }^{8}$ Nonetheless, thanks to Cox and others, Chinookan women received an inaccurate, lascivious reputation similar to that of Pacific Islanders. ${ }^{9}$

"Enlightened" scholars desired information about sexuality as part of the "scientific" component of the expedition. Biddle obliged: "Among these people, as indeed among all Indians, the prostitution of unmarried women is so far from being considered criminal or improper, that the females themselves solicit the favours of the other sex, with the entire approbation of their friends and connexions." Biddle's account-though none of the journals - notes that the prostituted young women were daughters and nieces of Chinookan men and women conducting trade with the explorers. ${ }^{10}$ Although sexual behavior, values, and mores are nearly as diverse as human societies are numerous and such observations should not be dismissed uncritically, the evidence does not support Biddle's conclusions that the Chinookan peoples prostituted junior female kin. The several journals mention only one group of young women as prostitutes, and prostitution seems to have been an infrequent and minor activity for them. The six women acted under the direction of a Chinook headman Delashelwilt from qwatsa'mts (Chinook proper) or, more accurately, under the orders of his wife, commonly referred to as "the old baud." The Corps encountered the group three times: 2I November I805, I5 March I806, and shortly after departing Fort Clatsop, probably 24 March $1806 .{ }^{11}$ Biddle added "her daughters \& nieces" where Clark had written only "her 6 young squars." 12

The women's supposed status as kin stemmed perhaps from conflating a separate story in which a family member was prostituted, as related by Clark to Biddle four years later in an interview. However, the man intended a custom-of-the-country marriage, not prostitution. Clark told Biddle that "a Clatsop whom I had cured of some disorder brought me 
out of gratitude his sister." Clark apparently ignored her and, after she stayed "two or three days in [the] next room with Chabono's wife [Sacajawea]" and "declined the solicitations of the men," she returned to her village. ${ }^{13}$ The lower Chinookan peoples were accustomed to the common fur-trade practice of informal or custom-of-the-country marriages through contact with maritime traders. Most famously, one woman bore a tattoo "J. Bowman," referring most likely to a mariner from a seasonal trade ship and suggesting such a relationship. ${ }^{14}$ Further, the published accounts often conflicted with the original journals, in which authors enhanced juicy details. In the published version of Sergeant Patrick Gass's journal of I8II, for example, the number of "the old baud's" prostitutes grew from six to nine and their encounters from three to "frequently." 15 Although Gass included this statement under the entry date of 2I March I806, it is part of longer, rambling commentary ruminating on all the "Flatheads" west of the Rocky Mountains and seems likely to have been written later and with publication in mind.

Indeed, the Corps's journals make it clear that the encounters were not frequent. On the second meeting on I5 March, Lewis and Clark both commented that "this was the same party that had communicated the venerial to so many [Clark says "several"] of our party in November last," and they advised their men to avoid contact. The attribution of so much venereal infection is noteworthy as well since only one expedition member, Silas Goodrich, is explicitly mentioned as having contracted the disease, likely syphilis, in Oregon. ${ }^{16}$ Finally, according to Sergeant John Ordway's journal, which was not rewritten for publication, the third encounter with the "old baud" and the six young women occurred on the river and consisted of their offering "a Sea otter Skin dryed fish \& hats for Sale," not themselves. ${ }^{17}$ Compared with the original journals, the published accounts of the expedition overstated and misrepresented the prostitution of the six young women.

The last piece of evidence from the Corps's journals for the Chinookan peoples' supposed propensity to prostitute family members derives from an interaction between the captains and a young Clatsop man of some status named Cuscalar. The captains first met Cuscalar when visiting his village on 9 December 1805 , shortly after the Corps established Fort Clatsop nearby on the south bank of the Columbia, where they awaited spring to return across the Rocky Mountains. Two weeks later, on 23 December, Clark learned that Cuscalar was ill and "sent him a little pounded fish [because Cuscalar] could not come to See us." The following day Cuscalar, his brother, "and 2 young Squar" came to Fort Clatsop, presenting mats for Lewis and Clark "and a parcel of roots" in exchange for two files, 
which the lower Chinookans prized for woodworking. Clark decided he could not afford to part with the tools and refused the trade, "which displeased Cuscalah a little. He then offered a woman to each of us which we also declined axcepting which also displeased them." The identity of the two women is unknown. Neither seems to have been the wife of Cuscalar because she was identified on a visit five days later and Clark made no connection between them. The intent of Cuscalar and his brother is equally unclear; the captains assumed prostitution, but establishing a beneficial kinship through custom-of-the-country marriage may have been their goal. Although Clark identified Cuscalar as "the young Clatsop chief," he had not bestowed on him a chief medal as he had on the elders Coboway and Comowool. Cuscalar may have been seeking to advance his position vis-àvis the new traders through their curious ranking system, viewing Clark's gift of pounded salmon as an opening. The anthropologist Theodore Stern notes that regular trading partners in the native Columbia trade network did not barter as much as they presented reciprocal gifts. In this light, Clark's pounded salmon and the mats and roots of Cuscalar take on a different meaning, particularly because Cuscalar fully expected the files and became upset when Clark balked. Marriage facilitated such trading partnerships. Still, the journals do not reveal Cuscalar's and his brother's intentions or the women's status, high ranking or lowly. The women may even have been slaves as was the young cook whom Cuscalar offered to trade to Clark for "some beeds and a gun" on 28 February. ${ }^{18}$

By the I790s, slave raiding and trading became integral parts of native Northwest interactions, as competition rose with colonial trade and imported disease pressured populations. Indeed, Leland Donald, who has done the most exhaustive research on Northwest Coast slavery, concludes that the fur and slave trades expanded together, reinforcing each other. ${ }^{19}$ Lewis and Clark commented that Cuscalar had purchased his cook from Salishan Tillamooks, who had taken him from a "great distance" down the coast. Both men also stated that Chinookan families adopted slaves and treated "them as their own children." 20 The debate regarding how well slaves were treated remains open, but the important question here is that of the identity of the women purportedly offered in trade. As the anthropologist Yvonne Hajda has argued, "Many of the women whites took to be relatives were probably slaves." Chinookans with any social standing had flattened heads and, ideally, slaves were captured or traded from "round-headed" peoples, derisively known as claxstars. Chinookan parents tied their infants' heads to cradleboards to produce the desired mark of distinction and beauty. By I805, reflecting increased competition and raiding, the practice extended up to the middle Columbia, leading to 
the Corps's tendency to refer to most Indians west of the Rocky Mountains as "Flatheads." Indeed, Kalapuya bands of the Willamette Valley, Chinookans, and Coast Salish peoples from the Alsea River on Oregon's central coast to the Quinault on the Olympic Peninsula flattened their heads. Hajda has further argued that the various ethnic groups adopted the Chinookan practice partly to protect women from slave raids. Adopting the Chinookan mark of distinction also added to their prestige regionally and made it more likely that an advantageous marriage could be arranged with the increasingly powerful Chinook, whose village qwatsa'mts occupied a principal position in the lower Columbia maritime trade. On the eastern and southern frontiers of the greater lower Columbia region, only girls' heads were flattened.21

Although few in number, many if not all native women that the Chinookans prostituted were likely slaves. Young women captured or obtained through trade, while not chattel, had little social status or control over their bodies. Slavery made one effectively kinless, without a local identity that others were bound to respect. Emphasizing slaves' otherness, Chinookans commonly named them for their country of origin. ${ }^{22}$ Slavery existed prior to the fur trade, but under slavery it grew and took on new purposes. Prostitution arose as a nexus. Throughout the Pacific trade, maritime encounters between male sailors and native women were sometimes sexual and almost always fleeting; indigenous peoples varied in their responses to the challenges posed to their constructions of gender, sexuality, and social structure. In the havoc-wrought world of the I790s and early I80os, Chinookans sought social stability by using slaves for sexual labor. Women, seized in raids and traded away, arrived on the lower Columbia without kin relations, thus with no social status or protection afforded by their lineage. The transformation of women into slaves could subsequently be reversed by marriage, establishing a kin connection to the community. With the growth of the Northwest Coast fur trade, slave women filled the newly created role of prostitutes..$^{23}$ Still, the prevalence of prostitution on the lower Columbia did not match the exaggerated claims of the published Corps accounts, and the Chinookans clearly sought more stable connections through intermarriage.

It may be, as James Ronda has argued, that "the Chinookans, whose lives focused on trading and material wealth, saw sex as an equally valid way to amass the goods that signaled power and prestige." ${ }^{4}$ Unfortunately, however, the way this nascent, ancillary sex trade worked in the first decade of the nineteenth century remains unclear. During the Corps's stay, two conclusions seem evident: custom-of-the-country marriages were sought by high status and ambitious Chinookans, and prostitution existed 
in a limited and casual form. Seeking to maintain or improve status through marriages with the newcomers was in keeping with Chinookan practices. The six ostensible prostitutes acted under the direction of Delashelwilt's wife and engaged in what might be termed prostitution once and possibly offered a second chance to the Corps, suggesting that such material-sexual exchanges existed by 1805 . With hindsight, these women may be seen as archetypal: they were directed by others, and sex work was not a principal or frequent labor. Their probable slave status suggests that the Chinook were beginning to incorporate a form of prostitution into their version of slavery to meet the challenges of a rapidly changing world.

\section{Permanent Colonial Presence Established, I8I I-I82I}

With the departure of the Corps of Discovery in the spring of 1806 , the Pacific trade continued as a series of irregular maritime encounters until I8II with the construction of Fort Astoria, again in Clatsop country on the south bank of the lower Columbia. As always in the North American fur trade, the company employees established "tender ties" with native women..$^{25}$ Unlike the sexual relations between lower Chinookans and the Corps, the permanent colonial presence of the fur trade offered a fuller account of wide-ranging relationships. At one end of the spectrum, Chief Trader Duncan McDougall and the Chinook headman Comcomly negotiated a formal diplomatic and economic union through the marriage of McDougall and Comcomly's daughter, Ilche ("Moon Girl”). More typical and less formal, several traders, trappers, and fort employees maintained monogamous relationships with lower Columbian women for varying durations, from weeks to years. At the other end, brief sexual encounters involved a simple trade transaction by native women who appeared to have little choice. In other words, they involved prostitution.

If McDougall or Ilche had any affection for each other before their marriage, his company log entry from their wedding day, 20 July I8I 3 , does not reveal it. Instead, the log shows only cold calculation to benefit the trade. McDougall dryly indicated that "for some time past [I] have in treaty with Comcomly for a female branch of his family to remain at this place." Presumably, such an arrangement would be a step above Comcomly's son Chalowane's employment on the Dolly, which had effectively advanced the trading relationship. McDougall claimed that "the old man" was flattered, and for the purposes of trade, "we conceive [the union] will be the means of securing to us his friendship more effectually than any other measure that could be adopted, and for which purpose only it was proposed." McDougall described the event mechanically, as he recorded 
most daily fort occurrences: "In the afternoon received a visit from him for the purpose of finally settling the agreement spoken of. The female was brought, and the presents agreed on delivered; after which his people took leave without further ceremony." Actually, the parties had not settled the agreement yet. Native marriages involved reciprocal gifts and subsequent exchanges. ${ }^{26}$

Indeed, approximately two weeks later, McDougall noted that "Comcomly brought over forty Salmon as a present, on account of the late arrangement with him." ${ }^{27}$ Nearly a year later, in the summer of I8I3, a second round of gifts settled the marriage agreement. With obvious sarcasm and disdain, Alexander Henry recorded on 25 April I8I4 that "McDougall this afternoon completed the payment for his wife to Comcomly. ... He gave 5 new guns, and 5 blankets, 2 I/ 2 feet wide, which makes I5 guns and 15 blankets, besides a great deal of other property, as the total cost of this precious lady. This Comcomly is a mercenary brute, destitute of decency." 28 An ardent critic of McDougall's management of Fort Astoria, Henry undervalued the union that joined the two "villages." Henry's may not have been a representative opinion, however; Alfred Seton wrote that "every thing went on well [at Fort Astoria in I8I4] owing to Mr. McDougall's marriage with Comcomly's ... daughter." 29

Seton's positive assessment may have been true economically and diplomatically. Socially, however, Ilche's assumption of her role as Astoria's headwoman created disruptions in the diverse fort community. In native villages throughout coastal Oregon, headwomen and first wives commanded high social status, overseeing the labors of lower-ranked women, lesser wives, children, and slaves, and often conducted intervillage diplomacy and trade. ${ }^{30}$ Their power was a common cause of comment from Western men unaccustomed to the public influence of women. According to Alexander Ross, "a Chinooke matron" accompanied by slaves "obsequious to her will" would "trade and barter ... as actively ... as the men, and it is as common to see the wife ... trading at the factory, as her husband." 31 Ross Cox similarly noted the power of "chieftainesses," who "possess great authority" on the lower Columbia. ${ }^{32}$ Indeed, the traders depended greatly on the diplomacy of "Madame Coalpo" after a conflict near The Dalles in I8I4. She was a powerful figure in the trade: married to Clatsop headman Coalpo and related to leading families upriver to the Cascades Rapids, she had influence that stretched the length of the lower river. A decade later, in 1824 , George Simpson claimed that she - not Coalpo- "rule[d] the Roost," and her I829 threats to abandon trade with Fort Vancouver in favor of U.S. coasting vessels brought gifts and a capitulation to her demands from Chief Factor John McLoughlin. ${ }^{33}$ With her I8I3 marriage 
to the headman, Chief Trader McDougall, Ilche could reasonably expect a degree of deference and authority at Astoria and to be ranked above other women and laborers, regardless of race. Indeed, Alexander Henry complained that "the lady" was "haughty and imperious." 34

However, Indian women at Astoria were not all native to the lower Oregon Country. Both the Pacific Fur and the Northwest companies hired Iroquois and other eastern native people to trap, hunt, and labor for the far western fur trade. The differences between Chinookan and Iroquoian social norms were readily apparent. Iroquois women did not recognize rank in the same fashion as Chinookans. ${ }^{35}$ Clan mothers were respected elders and had important responsibilities in Iroquoian society, but there was no position comparable to Ilche's headwoman status among the largely egalitarian horticulturalists of the Northeast. ${ }^{36}$ Unfortunately, the interactions of the native women from either end of the continent rarely entered the record, with the following exception offering only a suggestive peek. Upset with Iroquois hunter Ignace Salhione's children for "playing with some trifling things," Ilche entered the Iroquois family's tent, "took the playthings from them and set them bawling." According to Henry, Salhione's wife [anonymous as usual] responded by slapping Ilche; "Royalty was offended, and a dreadful row ensued." A disapproving Henry noted that McDougall intervened the following day and "revenged the insult offered to his lady" by "slapping and kicking Ignace's boy." ${ }^{37}$ Five days later, McDougall gave Comcomly the second round of marriage gifts, though if there was a connection to Ilche's humiliating slap from the wife of a hunter, Henry missed it. Unfortunately, McDougall kept no journal after being temporarily relieved of his command following the sale of Fort Astoria to the Northwest Company six months earlier. There is no mention of if or how Salhione and his wife responded to McDougall's abuse of their son, but company personnel records indicate that the Iroquois family returned to Montreal at the end of the I8I4 trapping season. ${ }^{38}$

The majority of monogamous relationships between company employees and native women produced a predictably scant record compared with that of McDougall and Ilche. Alexander Ross noted one other union similar to McDougall and Ilche's: a marriage arranged by the Astorians with "Chief How-How" specifically to "pave the way for our trappers and hunters to return to the Cowlitz." 39 For the most part, writers did not mention intermarriages between native women and colonials. Quite simply, few men besides traders and clerks kept journals, as many trappers were illiterate. There are passing references to "William's woman" or "two women" who accompanied their husbands on a trapping expedition. ${ }^{40}$ Mariner Peter Corney mentioned vaguely in I8I7 that "the whole 
of the settlers do not exceed one hundred and fifty men, most of whom keep Indian women." 41 Similarly, in 1828 , the "Rocky Mountain man" Jedediah Smith remarked on the many mixed-blood women "treated as wives" during his winter on the lower Columbia. ${ }^{42}$ As George Roberts, an officer of the company put it, "The flower of the lower Columbia women were wives to the Company's laboring men." 43 Such comments suggest that, by the late I8IOS and I820s, custom-of-the-country marriages were beginning to displace prostitution in colonial sexual relations.

Still, complaints most often seemed to have caused comment regarding intermarriages such as McTavish's refusal to sleep in his quarters after his two roommates "took each of them a Chinook woman." 44 Cox claimed that "numbers of the women reside during certain periods of the year in small huts about the fort from which it is difficult to keep the men." Cox unequivocally considered all such sexual encounters prostitution, though he noted that the men and women might stay together for weeks. The "certain periods" he refers to are the early summer and late fall, when voyageurs were present at the lower Columbia fort. Cox did not consider that the trappers might be returning to the same women or might hold affections deeper than those of prostitution. That the men were protective of Chinookan women, however, seems evident in an altercation between one "Mac" and Jane Barnes, an adventurous English barmaid who resided at the fort temporarily in the summer of I8I4, the only "white" woman on the lower Columbia for decades. Barnes disparaged "the native and half-bred women," "violently" attacking their "characters ... and [Mac] recriminated in no very measured language on the conduct of the white ladies," presumably of lower-class Portsmouth tavern society. Cox states that "Mac" subsequently complained to him of Jane's "contempt on our women, and may I be $\mathrm{d}-\mathrm{d}$ if the $\mathrm{b}-\mathrm{h}$ understands B from a buffalo!" Cox concluded mildly, "He judged her "poor indeed." 45 Trappers and traders valued native women as much for their "tender ties" as for their practical knowledge, labor, and experience. Without them, the fur trade would not have succeeded. ${ }^{46}$ Similarly, for Chinookans, intermarriages fostered advantageous relations in the developing fur trade.

\section{Race, Gender, and the Limits of Colonial Accommodation}

Prostitution was one of the most common and least evidenced complaints in the traders' discussions of Chinookan women. Clearly, ethnocentrism played a major role in this and other negative depictions of lower Columbia women, as critics used the ideal of Western femininity as a gauge. For 
nineteenth-century Westerners, women fit roughly into one of two idealistic categories: chaste or "loose." Chastity was an ideal that Western women of "the better sorts" (wealthy or noble) embodied in their conservative dress, demeanor, and actions. Any violation might damage their reputation and render them unchaste. The colonials' models for unchaste women, on the other hand, were the working poor of early industrial England and the growing cities of the United States. Displaced rural populations and impoverished immigrants could not afford to purchase "chastity," and the economic disruptions of modernity thrust prostitution, whether occasional or full-time, onto many women as a means of survival. ${ }^{47}$ As an ideal, chastity purposely could not be reached by many Western women; it was one of several ways of sorting the population into better and lower orders. Not surprisingly, this language made its way into colonial discourse to demean native women of the lower Columbia. One observer readily compared Chinookan women with "their frail sisters at Portsmouth," an English port town infamous for its taverns, brothels, and desperate poverty. ${ }^{48}$

Unwittingly, the Chinookan women violated Western notions of chastity. They bathed daily on the open shoreline of the Columbia and, according to the voyeuristic voyageur Alexander Henry, who deemed them "disgusting creatures," they were "devoid of shame or decency." ${ }^{49}$ Even when Chinookan women were dressed, Western observers frequently complained of their "nakedness." Where Anglo women were stifled under layers of linens, woolens, and contorting stays, Chinookan women wore only skirts woven from cedar bark that hung in strands from a waist belt. From I805 through the I830s, Western observers ceaselessly commented on what the cedar-bark skirts did and did not reveal in various postures. ${ }^{50}$ The Northwester David Thompson made the connection between dress and sexuality explicit, concluding that "from what I could see and learn of them they are very sensual people." 51

Besides idealized Anglo women, colonials had another source of comparison to disparage "naked" Chinookans: native women of the Columbia Plateau or "upper Oregon Country." Seeking to control the trade and claim the territory of the massive Columbia Basin, competing colonials raced to establish relations with native peoples throughout the interior of the Pacific Northwest. Brigades from Astoria moved quickly upriver, and the Northwesters moved downriver from the Columbia headwaters establishing small trade forts beginning in I8I2. By the late I8Ios, forts were strewn throughout the region. Not surprisingly, the Sahaptian and Shoshone women the colonials met wore more clothing than lower Chinookans; they lived in the high desert country where the weather is colder and more severe than the sea-level Columbia estuary, which is warmed by 
currents from the Pacific. As well, the cedar-rich forests, which supplied Chinookan clothing materials, stop at the Cascade Mountains, which trap most of the substantial moisture on the west side and leave Ponderosa and Lodgepole pines and other species of conifers tolerant of dry conditions to dominate the eastern plateau and canyon country. East of the Cascades, people made their clothing from animal hides. Cox swooned over the Wallawalla women of the middle Columbia: "The females . . . were distinguished by a degree of attentive kindness, totally removed from the disgusting familiarity of the kilted ladies below the rapids, and equally free from an affectation of prudery. Prostitution is unknown among them; and I believe no inducement would tempt them to commit a breach of chastity." 52 Thompson offered similar appraisals as he returned up the Columbia in I8II: "We no longer had to see naked females, many were well clothed, all of [the Nez Perce women] decently with leather, and in cleanly order, it was a pleasure to see them." This in stark contrast to the Chinookan women downriver who, he charged, "had scarcely a trace of the decency and modesty of the upper country women." ${ }^{33}$ Further, Chinookan women did not defer to men and were central to fur-trade economics. Sahaptian women on the middle Columbia, according to the traders, were demure, further endearing them to the Westerners.

The only Anglo woman on the lower Columbia for comparison was Jane Barnes. She arrived in April I8I4 at the relatively stable colonial settlement, which had recently passed from U.S. to British control when Astor's former Northwesters sold out to current Northwesters during the War of I8I2. The establishment was renamed Fort George and, although the United States managed to reinstate its claim diplomatically and New England ships continued to dominate the maritime trade for another decade, the British became the fixed colonial presence. Despite these imperial changes, colonial relations lost none of their fluidity and adaptive nature. Though Barnes's stay was brief, she caused considerable competition and comment among potential suitors, and her treatment points to the extent to which, in a colonial setting, gendered and sexualized racial ideologies could mitigate a "white" woman's class status by demeaning native women.

By the standards of her day, Barnes was unchaste; as mentioned above, Cox's "Mac" certainly thought so. Barnes had met Donald McTavish in her capacity as barmaid in Portsmouth and she had agreed to accompany the aging Northwester to the Oregon Country and back without being married to him. Cox suggested that she regretted leaving home, having agreed to the overseas adventure "in a temporary fit of erratic enthusiasm"; on the lower Columbia, she became an object of competition between 
McTavish and Chief Trader Alexander Henry. ${ }^{54}$ According to Henry, he and McTavish negotiated her position over the course of a week and arrived at a settlement, although "we differ on some personal points." The continuing points of contention probably owed much to Barnes's being lodged in Henry's quarters rather than with McTavish or aboard the Isaac Todd, on which she departed some weeks later to Canton, China, eventually going back to England. Both men were concerned for her physical wellbeing and her reputation: "to cause no misunderstanding with the young gentlemen, etc." Indeed, the two were linked: if considered unchaste, the men feared that Barnes might be raped, or as Henry called it suffer "ill usage." ${ }^{55}$ McTavish apparently recovered from his loss of Barnes's affections quickly and married a Chinook woman on I9 May I8I4, but three days later both he and Henry drowned while paddling out to the Isaac Todd's anchorage.

Contrary to the elder gentlemen's fears, Barnes's status improved after their demise. Cox claimed that the "flaxen-haired, blue-eyed daughter of Albion" became an honored figure for the remainder of her stay, as suggested by his hyperbolic description. Ignoring her lowly background in England and unchaste activities since, he deemed her worth "a score of the chastest brown vestals that ever flourished among the lower tribes of the Columbia." Latent racism reared up, demeaning native women, and the presence of an Anglo woman challenged local, colonial gender relations. Further, when the Chinook headman Comcomly's eldest son Cassakas approached Fort George to cement further the ties between the two peoples in the spring of I8I4, his marriage proposal for Barnes was uncategorically rejected. Barnes reportedly replied in quasi-religious racial terms, based on "certain Anglican predilections respecting mankind ... among which she [and her country] did not include a flat head, a half naked body, or a copper-coloured skin besmeared with whale oil." ${ }^{56}$

Interracial marriage, and any sexual interaction, worked in only one direction: male Westerner and female native. This distinction made little sense to Cassakas, whose sister Ilche had married Chief Trader McDougall the year before; both were children of Concomly, who was one of the most important figures in the trade and who had successfully used marriage to advance the Chinook's trading position vis-à-vis other native villages. Cox claimed that after this and subsequent refusals, Cassakas had a plan to kidnap Barnes, which resulted in her having to abandon her accustomed evening walks on the beach. Barnes's status was premised on her racial identity, which included-in a colonial setting-a pass from unchaste to chaste, but this conditional uplift apparently included checks on her freedom of movement, which was integral to the ideal of chastity. ${ }^{57}$ Moreover, 
Barnes's local transformation from a barmaid into a "lady" suggests both the extent and the limits of colonial accommodation. Clearly, she could transcend her lowly position in English society. However, gendered and sexualized "whiteness" remained among the strongest structuring principles of nineteenth-century Western culture and limited the extent to which colonials would join with indigenous people to create practical forms of social relations. Keeping Barnes outside of the developing world of gender and sexual relations was as implicitly understood by colonials as it was incomprehensible to the Chinook, who had no notion comparable to race.

\section{Prostitution and Sexual Liberties on the Lower Columbia, I8Ios}

Although formal and informal marriages increased in the I8Ios, the prostitution of slaves, with all its implications of exploitation, continued. For example, some weeks after his arrival on the lower Columbia, in late January I8I4, Chief Trader Henry saw the corpse of one of the slaves belonging to Coalpo's family lying outside the fort. "The poor girl had died in a horrible condition, in the last stage of venereal disease, discolored and swollen, and not the least care was ever taken to conceal the parts from bystanders." ${ }^{8}$ After some prodding, Coalpo, a principal Clatsop headman and "medal chief" since the days of Lewis and Clark, sent people to remove the body, which they dragged away and unceremoniously stuffed into a hole with canoe paddles.

The writings of consecutive chief traders McDougall and Henry suggest that prostitution around the fort increased in the early and mid-I8Ios. In I805, during the Corps's stay, there had been less impetus to foster the role of prostitutes, with only the occasional coasting vessel arriving for brief periods. With the establishment of Fort Astoria (George), the practice had clearly developed with the regular presence of Western, male traders and trappers. Subsequent chief traders tried to stop prostitution, fearing that venereal disease would hinder their laborers' productivity. In December I8I2, McDougall demanded that Coalpo send the "girls" away and became frustrated when he later learned that the Clatsop had only "concealed" them instead. McDougall ordered Coalpo and his encampment to leave their site below the fort but tried to ameliorate the rejection by offering tobacco. Coalpo refused the present and claimed he would never enter Fort Astoria again. ${ }^{59}$ Prostitution had become a lucrative part of the relationship with the colonials and not one to be readily surrendered: as evident from Henry's complaints two years later, Coalpo neither stayed away from the fort nor discontinued the prostitution of women whose behavior he controlled, most likely slaves. 
The Chinookans and Henry had opposing economic interests regarding sexuality. In early I8I4, with two men incapacitated by venereal disease, Henry feared that "the foul malady" would affect half his men by spring "and may seriously affect our commerce." 60 Venereal disease had been evident among the Astorians long before they reached the Columbia: McDougall recorded cases on board the Tonquin after leaving New York in I8Io and one of the Kanaka, Thomas Tuana, brought it with him from Hawai' $i$ in I8II. From April I8II through the autumn of I8I3, McDougall's sick-call registry often indicated three or four men infected, receiving mercury "treatments," or recovering from bouts of venereal disease. ${ }^{61}$ By I8I4 Henry claimed that the disease, likely syphilis, was "prevalent among our people and the women in this quarter." He could not force his men to refrain from sexual interaction, though his paranoia about the disease seems to have spread. Henry noted that Cartier "discharged his lady" after discovering two pimples. Cartier's roommate "Bethune keeps his, though he is very dubious of her." Because Henry drowned two weeks later and fort record-keeping suffered as a result, we do not know if Cartier's pimples indicated anything.

While venereal disease was a real problem for the native and colonial communities, it may have been overstated, becoming confused with skin conditions that reflected seasonal nutritional imbalances. Henry noted in mid-March that Chinookan women began bringing "a quantity of cranberries and some roots." He claimed further that "this vegetable diet has the good effect of purifying the blood and cleaning them of scabs.... even venereal disease is checked by this diet, and sometimes cured." ${ }^{2}$ Cranberries, wapato, camas, and licorice roots do not cure syphilis anymore than the colonials' concoctions of mercury "quick-silver" ointments or Paul Jeremie's experiment in which he submerged the hapless Tuana inside a horse freshly killed and disemboweled for his "cure."63

Prostitution had political effects as well. McDougall alienated Coalpo in December I8I2 when he ordered him "to be off with the whole of his people immediately" and destroyed "the remains of their houses" at the Clatsop's encampment on Point George. In addition, other lower Chinookans were clearly concerned that women from their villages could be taken and enslaved as prostitutes. Two days after McDougall's confrontation with Coalpo, representatives from an unnamed Chinookan group "living a few miles behind us in Young's Bay" arrived at the fort. They were searching for a woman who had been lost in an overturned canoe a couple of days earlier. One of their slaves returned to the village and reported having left her alive on the shore. With Coalpo's recent abrupt departure, they thought that she either had been taken away by the Clatsop or that was she was being held at the fort. McDougall denied any knowl- 
edge and accused their slave of lying. Four days later, McDougall noted that the missing woman had been found, resolving a situation that could have fueled an altercation. ${ }^{64}$

In his six months on the lower Columbia, from November I8I 3 to his death in May I8I4, Alexander Henry tried to reform fort conduct, which included the access of native women traders. He evidenced little experience with or tolerance for women conducting trade. His inexperience on the lower Columbia led him to accuse nearly every canoe of female traders of being prostitutes, chasing them off the beach even when they were obviously toting food and their woven manufactures, and he threatened to put women in irons. He claimed, for example, that some Clatsop women who came to trade cranberries had also come to trade "their precious favors." To support his claims, he noted one instance in March I8I4 when "several Chinooks who had slept here, mostly women, barter[ed] their favors with the men." 65

Gabriel Franchère, a French-Canadian clerk who resided on the lower Columbia from April I8II until September I8I4, did not term such liaisons prostitution. According to Franchère, the women's behavior was culturally accepted premarital sexuality. He concluded that "few marriages would occur [among Chinookans] if the young men wished to marry only chaste young women, for the girls have no qualms as to their conduct and their parents give them complete liberty in that respect." 66 Social status, however, affected this sexual openness, at least with the advent of colonialism. In I824 Governor George Simpson cited the case of one of Madame Coalpo's daughters to claim that chastity was protected to appeal to the preferences of colonial traders. ${ }^{67}$ Although Simpson cast his net broadly, his example of one of the leading lower Chinookan families was less representative than Franchère's broader characterization of the general population with which he had regular contact from I8II to I8I4.

Social status is the key: high status, which indicated a relatively higher degree of material wealth and power, necessarily limited the agency of young women from leading families such as Coalpo's. By the first decades of the nineteenth century, power and prestige were becoming tied to the colonial traders. Western gender and sexual norms (modified by the realities of distant colonial life) shaped Chinookan norms regarding premarital sexuality from the top down. Conversely, young women from less prestigious families expressed a degree of autonomy by having sexual relations with colonials and obtaining "baubles" for themselves, as Franchère put it. A material exchange in interracial sexual encounters did not necessarily mean prostitution, from the lower Chinookan perspective. Instead, much of this sexual interaction-perhaps the majority - fit into the norms of life 
stages, namely premarital behavior, and individual material acquisition. In the I8Ios, prostitution, while economically important to such Chinookan leaders as Delashelwilt and Coalpo, was less common than casual sexual encounters engaged in by Chinookan women exercising their premarital "liberties."

\section{Colonial Lower Oregon, I82 I-I 838}

The next two decades witnessed massive demographic change. By the I820s, colonial-indigenous relations had stabilized on the lower Columbia, and families represented much of the interracial gender and sexual constructions. These were not only Chinookan women and Western men. Native Hawaiian women (Wahines) began to arrive as early as I8I2, for example. ${ }^{68}$ Subsequently, other Wahines accompanied their Kanaka husbands as Hudson's Bay Company employees through the I830s. ${ }^{69}$ Together with the Nipissing, Iroquois, and others, transplanted indigenous peoples accounted for the earliest colonized families in the Oregon Country, predating the Euro-American "hardy pioneers" and Red River Métis by decades. Fur-trade economics in the I8IOS and I820s explain these initial population shifts, but in the next decade, disease caused the greatest changes.

Between I830 and I834, annual malaria epidemics ravaged the native population of the lower Columbia; and successive horrific waves of disease devastated the Chinookans and many other Indian peoples of the region through the I840s. The anthropologist Robert Boyd estimates the death toll among Chinookans and the neighboring Kalapuya at 88 percent between I830 and I84I, their population declining from nearly sixteen thousand people to fewer than two thousand..$^{70}$ Blaming insufficient supplies in the early I830s, the traders only administered quinine treatment to the Indian peoples in closest proximity to the fort, such as the wives and families of company men. Malaria subsided in I834, and in the same year American trappers arrived from the declining Rocky Mountain fur trade and took homesteads in the Willamette Valley, where the Kalapuya had recently thrived. Faced with radically altered demographics and renewed U.S. competition, British imperial officials sought to reform their colony on the Columbia. The remaining discussion concerns colonial life around what became the principal establishment, Fort Vancouver.

After a forced merger with the Northwest Company in I82I, the imperial monopoly, the Hudson's Bay Company, took charge of the new "Pacific Department" and instituted a series of reforms, which eventually included dispatching Reverend Herbert Beaver in I8 37 to see to the colony's 
moral, social, and spiritual character. Beaver complained that the lack of a "civilized population" was no way for England to conduct its "infant colony" and to establish "perhaps a future London" on the Pacific. Rather, the Company board must send "hither a few respectable English families of the labouring class." Later, American missionaries reacted similarly to Beaver, though they, of course, favored colonization by white, Christian families from the United States, not England. Amid the economic upheaval of the late I830s and I840s that fueled the migration of "hardy pioneers" to Oregon, England did export part of its "surplus" population. However, their destinations were the "white colonies" of Australia and New Zealand, where British imperial claims were unchallenged. ${ }^{71}$

At Fort Vancouver on the lower Columbia in I837 and I838, Beaver did his best to undermine the relationships that he neither could nor desired to understand. Deemed a more beneficial location several miles upriver, opposite the mouth of the Willamette River, Fort Vancouver had replaced Fort George as the principal establishment in 1825 . Governor George Simpson was upset with colonial life in I824 at Fort George, complaining about the "air of ... grandeur and consequence which does not become and is not all suitable to an Indian trading post." Worse, he noted that the native wives of company men kept prostitutes, whom they hired out to trappers. ${ }^{72} \mathrm{~A}$ decade later at Fort Vancouver, Beaver was equally concerned with the similar colonial life that developed as the fur trade declined, and Chief Factor John McLoughlin began shifting the trade settlement into a colonial center in which ploughs and livestock replaced traps and pelts. Reverend Beaver attempted to direct this changing culture.

In particular, Beaver felt that without a formal Christian ceremony the relationships between company men and native women in the huts surrounding the fort were "concubinage." Beaver was totally inexperienced with the North American fur trade or the type of human relations it engendered, his overseas experience limited to that of garrison chaplain on St. Lucia, and throughout his stay he complained that Oregon was not "civilized" like Britain's racially segregated Caribbean "black colonies." To counter "the beastly state of fornication," Beaver wanted the men bunked in the fort in a proposed bachelor's quarters and the "the native females, whether of pure or mixed breed," barred from residence, provisions, and medical attention. Beaver was not terribly popular among the Hudson's Bay men, not surprisingly since he considered their native wives to be "the very excrement" on the "scale of humanity." He refused to marry A. C. Anderson to the mixed-blood daughter of James Birnie (a clerk at Fort George) and his Clatsop wife. Having conducted "one marriage between two persons of the lower order, the man being Canadian, and the woman 
half-bred between an Iroquis and native woman ... in the present deplorable and almost hopeless state of female vice and ignorance, I have no desire to unite more couples." He deemed intermarriages on the lower Columbia "both irreligious and illegal." However, the following year, I838, he changed his mind and his tactics, recommending corporal punishment for all men who refused to marry officially their native "concubines." Beaver left later that year for a garrison chaplaincy in South Africa, frustrated that his many recommendations for civilizing native women in Oregon were ignored. The regimented racial lines between indigenous South Africans and European colonists better suited Beaver, and he remained there until his death in 1857.73

As Beaver made his various complaints and recommendations directly to London, Chief Trader James Douglas responded and, in so doing, provided information on custom-of-the-country marriages and prostitution on the lower Columbia during the late fur trade. Regarding the withholding of medicine and provisions as inducement to marriage, "our own people ... would absolutely redicule us." Besides, he noted, only five wives receive company rations and all "have claims to consideration." Regarding charges of prostitution, Douglas firmly stated that "no person is permitted to make fancy visits, and I neither have nor would suffer any person, of whatever rank, to introduce loose women into this Fort.” This was a marked change from the Fort George of I8I4-25, a change in which a fort domestic realm had become distinct from other sexual relations that could be considered prostitution. Rather, Douglas continued, the native women live "in a state of approval by friends and sanctioned by immemorial custom, which she believes strictly honourable." The women married by custom of the country form "a perfect contrast to the degraded creature who has sacrificed the great principle which from infancy she is taught to rever $[s i c]$ as the ground work of female virtue; who lives in a disgrace to friends and an outcast from society." 74

Thus, Douglas acknowledged prostitution on the lower Columbia but, unlike other writers, he differentiated it from the informal, monogamous unions and stated that prostitutes lacked social status and communal ties. What Douglas left unchallenged was Beaver's assertion that slaves acted as prostitutes at the behest of the native wives of company men, a practice that existed at least since Governor Simpson's complaint in I824. However, Douglas assured the board that such activities were not allowed in the fort and were not part of the colonial society. The sex trade, such as it was, had clearly declined. Prostitution, whether by "outcast" women or slaves, became a marginal activity by the I830s. In the I8Ios, native leaders such as Delashelwilt, Coalpo, and their wives had prostituted slaves; in the 
I820s, custom-of-the-country wives acted similarly. While prostitution in this manner did not cease, new conditions, such as diseases that decimated the native population, greatly curbed it. Colonization contemporaneously increased the predominantly male Western population, which sought intermarriages with survivors. Trappers turned homesteaders needed fellow agricultural laborers, not prostitutes, and Chinookans needed to rebuild shattered kin relations. Demonstrating his ignorance of fur-trade culture, Beaver termed Chinookan women "concubines," but these survivors of a microbial holocaust who took up with colonials were the next generation of custom-of-the-country wives. Ultimately, they and other Chinookan people continued their heritage.

\section{Conclusion}

Cataclysmic change shook the foundations of the native Northwest: the smallpox epidemic of the early I 78 os was followed by the maritime trade, the land-based fur trade, and the advent of settler-colonialism in the midI830s. On the lower Columbia River, Chinookans altered their society to meet these new, unprecedented challenges. No state existed to direct and implement change. Individual men and women from villages such as Clatsop, Chinook, and Clatskanie competed with one another and with colonials. They adapted established practices such as exogamous marriage and slaving to new circumstances and created new social roles such as prostitution. The lower Columbia fur trade was more than a one-sided, Western economic pursuit; inadvertently and sometimes purposely, the trade created a field of interpersonal and cultural relations that both created and destroyed.

An analysis of gender and sexual constructions reveals the complexities and fluid nature of these constructions. Intermarriage arose out of Chinookan and regional practice, in which the establishment of kinship ties cemented trade and diplomatic relations, as well as colonial, fur-trade custom-of-the-country marriages that dated back to the I60os east of the Plains. Intermarriages reflected both the practical realities of the colonial sex-ratio imbalance and the intercultural and interpersonal negotiations of power and position. Interracial sexual relations were in no sense "natural" - people contested and adapted them in response to changing conditions over time. Prostitution became a fault line in the early colonial world of lower Oregon.

The destructive practice of slavery expanded with the fur trade, and enslavement for the purpose of colonial sexual relations-prostitution-arose. Over time, prostitution declined in importance to both native 
peoples and colonials alike, but it was nonetheless an important and compelling feature of their world. Unfortunately, prostitution during the fur trade has largely escaped the eyes of historians of the American West, and this study is more a beginning than a final word. Albert Hurtado and more recently Susan Johnson have produced excellent studies of gender and sexual relations during the California Gold Rush, but the sheer numbers of "argonauts" and the scenario of the Far West after the conquest of Mexico produced a markedly different backdrop for colonialindigenous relations. Even works on Spanish colonialism such as Hurtado's and Ramón Gutiérrez's offer a poor guide because the roles of church and state were conspicuously unfilled further north..$^{75}$ In her study of the mid- to late nineteenth century, Anne Butler has argued rightly that "Indian prostitution was not peculiar to any one frontier location" in the American West, but her casting generalizes prostitution and native people. Indeed, like many scholars, Butler fails to account for the differences between the Northwest Coast cultures and those elsewhere in western North America. Butler's conclusion that prostitution reflected "the destruction of the Indian social order" in the American West does not readily fit lower Oregon where-initially-Chinookans intended prostitution to help maintain their social order by expanding and altering the role of slavery. ${ }^{76}$ Prostitution never remained static or easily defined. In the first decades of the nineteenth century, colonial officials made vain attempts to control gender and sexual relations for reasons varying from morality to health and economics. However, the decline of prostitution resulted more from demographic changes - primarily, disease and initial colonial settlement - and from individual choices about how to create order in the face of devastation. Gender and sexual relations were the sinews of indigenouscolonial encounters. As critical as the economic effects of the trans-Pacific fur trade are to our understanding of early-nineteenth-century colonialism and indigenous societies, the cultural history of everyday interactions among diverse individuals better reflects the realities of peoples' lives in this crucial period of change.

From the initial maritime encounters and the Corps of Discovery's founding of Fort Clatsop, lower Chinookan women established themselves as integral to economic, political, and social relations. With the rise of the land-based fur trade in the I8Ios, some women retained their important positions, negotiating their places in an increasingly complex colonial society. During a period of great change, high-status women reaffirmed their positions through intermarriage with traders, and lower status women attempted the same with trappers and other employees to improve their positions. Of the women who were prostituted to benefit others, we 
know little, although clearly they played an important if exploited role in shaping the nascent multiracial colonial society and rapidly changing native communities. A glimpse into the lives of all these women and men reveals much about a fleeting world that collapsed with the epidemics of the I830s and the subsequent onslaught of intensive settler-colonialism by citizens of and immigrants to the United States in the I840s and I850s.

\section{Notes}

I Following scholarly convention, the term lower Chinookan refers generally to the dozens of linguistically related villages that lined the lower Columbia and its tributaries from the Cascade Rapids to the Pacific Ocean; specific villages such as Chinook proper and Clatsop are also used. Salish-speaking neighbors such as the coastal Tillamook and other non-Chinookans are distinguished. The greater lower Columbia region includes territory dozens of miles up and down the coast and the lower sections of tributaries that feed the lower Columbia River, as the inhabitants interacted with each other extensively before, during, and after the fur trade; Yvonne P. Hajda, "Regional Social Organization in the Greater Lower Columbia, I792-I830," PhD diss., University of Washington, 1984; Verne Frederick Ray, "Lower Chinook Ethnographic Notes," University of Washington Publications in Anthropology 7 (1938): 37-4I.

2 Sylvia Van Kirk, Many Tender Ties: Women in Fur-Trade Society, 1670-1870 (Norman, OK, I980); Jennifer S. H. Brown, Strangers in Blood: Fur Trade Company Families in Indian Country (Vancouver, I980); James P. Ronda, Lewis and Clark among the Indians (Lincoln, NE, I988). For more recent work, see, e.g., Nancy Shoemaker, ed., Negotiators of Change: Historical Perspectives on Native American Women (New York, I995); and Susan Sleeper-Smith, Indian Women and French Men: Rethinking Cultural Encounter in the Western Great Lakes (Amherst, MA, 200I). Regarding "complete liberty," see Gabriel Franchère, Adventure at Astoria, I8IO-I8I4, trans. and ed. Hoyt C. Franchère (Norman, OK, I967), II7.

3 Jürgen Osterhammel, Colonialism: A Theoretical Overview (Princeton, NJ, I997), esp. 4, 2I-22; Ian Copland, The Burden of Empire: Perspectives on Imperialism and Colonialism (Melbourne, I990), 2.

4 "Interracial marriage involves the making and remaking of notions of race, gender, and culture"; Peggy Pascoe, "Race, Gender, and Intercultural Relations: The Case of Interracial Marriage," Frontiers I2 (I99I): 5-I8. The works of Pascoe and others evidence the value of intermarriage and related topics that bridge gender, race, and sexuality. See, e.g., Lucie Cheng Hirata, "Free, Indentured, Enslaved: Chinese Prostitutes in Nineteenth-Century America," Signs 5 (1979): 3-29; and Albert L. Hurtado, "When Strangers Met: Sex and Gender on Three Frontiers," in Writing the Range: Race, Class, and Culture in the Women's West, ed. Elizabeth Jameson and Susan Armitage (Norman, OK, I997), I22-42.

5 Gray H. Whaley, "Indians Twice Removed: Historical Representations of the Native People of Southwestern Oregon," in Changing Landscapes: "Telling Our Stories"- Proceedings of the Fourth Annual Coquille Cultural Preservation Conference, 2000, ed. Jason Younker et al. (North Bend, OR, 200I). 
6 Shannon Bell, Reading, Writing, and Rewriting the Prostitute Body (Bloomington, IN, I994). There is no evidence that prostitutes existed among Chinookans before the fur trade created the role. For a broader discussion of nineteenthcentury colonialism and prostitution, see Ronald Hyam, Empire and Sexuality: The British Experience (New York, I990).

7 See Cole Harris, The Resettlement of British Columbia: Essays on Colonialism and Geographical Change (Vancouver, I997); D. W. Meinig, The Great Columbia Plain: A Historical Geography, I805-I9Io (Seattle, I968); and Ronda, Lewis and Clark.

8 Ross Cox, The Columbia River, ed. Edgar I. and Jane R. Stewart (Norman, OK, I957), 4I-42.

9 For a discussion of such depictions in the neighboring "upper Oregon Country," see Elizabeth Vibert, Traders' Tales: Narratives of Cultural Encounters in the Columbia Plateau, I807-I846 (Norman, OK, I997).

Io Meriwether Lewis, The Lewis and Clark Expedition: The I8I4 Edition, Unabridged, vol. 2 (New York, I961), 482, 530.

II 2I November I805 and I5 March I806 incidents: Lewis, Lewis and Clark Expedition, 482, 542; and Gary E. Moulton, ed., Journals of the Lewis and Clark Expedition, vol. 6 (Lincoln, NE, I990), 73-75, 4I6-I8. 24 March I806 incident: Milo M Quaife, ed., The Journals of Captain Meriwether Lewis and Sergeant John Ordway, 2nd ed. (Madison, WI, I965), 33I.

I2 Moulton, Journals of Lewis and Clark, 75.

I3 Letters of the Lewis and Clark Expedition with Related Documents, I783-I854, ed. Donald Jackson (Chicago, I978), 503.

I4 Moulton, Journals of Lewis and Clark, 75 .

I5 James Kendall Hosmer, ed., Gass's Journal of the Lewis and Clark Expedition (Chicago, 1904 [1807]), 204.

I6 Moulton, Journals of Lewis and Clark, 239, 24I.

I7 Quaife, Journals of Captain Meriwether Lewis and Sergeant John Ordway, 33I; Ordway's journal was "found" in I9I4 (26).

I8 Moulton, Journals of Lewis and Clark, I20, I23, I36, 360.

I9 Donald, Aboriginal Slavery, 233.

20 Moulton, Journals of Lewis and Clark, 365-66.

2I Hajda, "Regional Social Organization," I78, I82; Ray, "Lower Chinook Ethnographic Notes," 5I-54, 69-70; Leland Donald, Aboriginal Slavery on the Northwest Coast of North America (Berkeley, CA, I997).

22 Ray, "Lower Chinook Ethnographic Notes," 53.

23 Donald, Aboriginal Slavery, 233-35.

24 Ronda, Lewis and Clark, 208.

25 Phrase borrowed from Van Kirk, Many Tender Ties.

26 Ray, "Lower Chinook Ethnographic Notes," 72-73.

27 Robert F. Jones, Annals of Astoria: The Headquarters Log of the Pacific Fur Company on the Columbia River, I8II-I8I3 (New York, I999), 203-4, n. 98.

28 Elliott Coues, New Light on the Early History of the Greater Northwest: The Manuscript Journals of Alexander Henry and of David Thompson, I799-I8I4 (Minneapolis, I965), 901.

29 Robert F. Jones, Astorian Adventure: The Journal of Alfred Seton, I8II-I8I5 (New York, I993), II6.

30 Hajda, "Regional Social Organization," I79-82. 
3I Alexander Ross, Adventures of the First Settlers on the Oregon or Columbia River, I8IO-I8I3 (Lincoln, NE, I986), I07.

32 Cox, Columbia River, I59-62.

33 Coues, New Light, 790, 800, 805; Frederick Merk, ed., Fur Trade and Empire; George Simpson's Journal; Remarks Connected with the Fur Trade in the Course of a Voyage from York Factory to Fort George and Back to York Factory, 1824I825 (Cambridge, MA, I93I), I04; McLoughlin to Donald Manson, I8 August I829, in Letters of Dr. John McLoughlin Written at Fort Vancouver, I829-I832, ed. Burt Brown Barker (Portland, OR, I948), 46.

34 Coues, New Light, 89I.

35 From the various sources of Forts Astoria (George) and Vancouver, the Iroquois and Algonquian women all appear to have been wives of trappers hired at Montreal and Michilimackinac.

36 Matthew Dennis, Cultivating a Landscape of Peace: Iroquois-European Encounters in Seventeenth-Century America (Ithaca, NY, I993), 28, I08-9; Daniel K. Richter, The Ordeal of the Longhouse: The Peoples of the Iroquois League in the Era of European Colonization (Chapel Hill, NC, I992), I8-24, 43-44.

37 Coues, New Light, 89I.

38 Jones, Annals of Astoria, 237.

39 Ross, Adventures of the First Settlers, $\mathrm{I} 30-3 \mathrm{I}$.

40 Coues, New Light, 908; Cox, Columbia River, 268; Jones, Astorian Adventure, I34.

4I Peter Corney, quoted in Grace P. Morris, "Development of Astoria, I8III850," Oregon Historical Quarterly (I937): 4I3-24, 4I7.

42 Smith in Dorothy Nafus Morrison, Outpost: John McLoughlin and the Far Northwest (Portland, OR, I999), I54.

43 Recollections of George B. Roberts, MS P-A 83, Bancroft Library, University of California, Berkeley, I5. See also discussion of "daughters of the country" in Van Kirk, Many Tender Ties, 95-I22.

44 Coues, New Light, 9Io.

45 Cox, Columbia River, I58, I66, 172.

46 Van Kirk, Many Tender Ties, 53-74.

47 Anne M. Butler, Daughters of Joy, Sisters of Misery: Prostitutes in the American West, I865-90 (Chicago, I985); Frances Finnegan, Poverty and Prostitution: A Study of Victorian Prostitutes in York (New York, 1979); Timothy J. Gilfoyle, City of Eros: New York City, Prostitution, and the Commercialization of Sex, I790-I920 (New York, I992); Linda Mahood, The Madgalenes: Prostitution in the Nineteenth Century (New York, 1990).

48 Cox, Columbia River, I66.

49 Coues, New Light, 754, 849.

50 Gass likely started the observational trend with his I8II publication; Hosmer, Gass's Journal, I76; see also Ross, Adventures of the First Settlers, Io6.

5I Richard Glover, David Thompson's Narrative, I784-I8I2 (Toronto, I962), 362.

52 Cox, Columbia River, 87.

53 Glover, David Thompson's Narrative, 357, 376.

54 Cox, Columbia River, I56.

55 Coues, New Light, 908-9.

56 Cox, Columbia River, I56, I58. 
57 Controlling Barnes would have been imperative for the creation and maintenance of a moral order. As Michel Foucault argues, morality is a complex interplay of regulations, restrictions, and the interplay of individual behavior with these codes; Foucault, The Use of Pleasure, vol. 2 of The History of Sexuality, trans. Robert Hurley (New York, 1985), 22-32.

58 Coues, New Light, 825-26.

59 Jones, Annals of Astoria, I40, I4I.

60 Coues, New Light, 835-36.

6I Jones, Annals of Astoria, 2, I0, 3I, 39, 66, I08, I33, I53, I58, I59, I9I, 201.

62 Coues, New Light, 836, 9II, 859.

63 For Jeremie's medical experiment, see Jones, Annals of Astoria, I36-37.

64 Ibid., I4I-42.

65 Coues, New Light, 890, 891, 806, 859.

66 Franchère, Adventure at Astoria, II7.

67 Hajda, "Regional Social Organization," I82.

68 Jones, Annals of Astoria, 89-90, n. I7; Cox, Columbia River, 45.

69 Thomas E. Fessett, Reports and Letters of Herbert Beaver, I836-I838: Chaplain to the Hudson's Bay Company and Missionary to the Indians at Fort Vancouver (Portland, OR, I959), 42, 54, 85, I3I.

70 Robert Boyd, The Coming of the Spirit of Pestilence: Introduced Infectious Diseases and Population Decline among Northwest Coast Indians, I774-I874 (Seattle, 1999), 84, and see tables, 323-29.

7I English settler-colonialism dated back to the I780s, but migration increased in the I840s as did the colonization of New Zealand. As in the Far West of the United States, emigration was spurred by a gold rush. See P. J. Cain and A. G. Hopkins, British Imperialism: Innovation and Expansion, I688-I9I4 (New York, I993), 229-3I, 243-58.

72 Simpson quoted in Frederick Merk, Fur Trade and Empire: George Simpson's Journal; Remarks Connected with the Fur Trade in the Course of a Voyage from York Factory to Fort George and Back to York Factory, I824-I825 (Cambridge, I93I), 65, IOI.

73 Fessett, Reports and Letters of Herbert Beaver, 35, 40, 50, 54, 57, 86, II7-2I.

74 Ibid., I40, I45, I47-48.

75 Ramón A. Gutiérrez, When Jesus Came, the Corn Mothers Went Away: Marriage, Sexuality, and Power in New Mexico, I500-I846 (Stanford, CA, I99I); Albert L. Hurtado, Indian Survival on the California Frontier (New Haven, CT, I988); Susan Lee Johnson, Roaring Camp: The Social World of the California Gold Rush (New York, 2000).

76 Butler, Daughters of Joy, II-I2. 